\title{
Thinking and Practice on the Construction of Management Science Major with Financial Characteristics
}

\author{
ChuanLiang JIA \\ School of Management Science and Engineering \\ Central University of Finance and Economics \\ Beijing, P.R.China \\ cnbjjcl@163.com \\ ShiMing LIU* \\ School of Management Science and Engineering \\ Central University of Finance and Economics \\ Beijing, P.R.China \\ liushiming1991@163.com
}

\author{
Jie SU \\ School of Management Science and Engineering \\ Central University of Finance and Economics \\ Beijing, P.R.China \\ sujie@cufe.edu.cn \\ AiHua LI \\ School of Management Science and Engineering \\ Central University of Finance and Economics \\ Beijing, P.R.China \\ neu aihua@126.com
}

\begin{abstract}
With the developing of society, "Management Science" is becoming more and more important for us to make decision in economic activity, but the development of Management Science major in domestic colleges and universities is not optimistic. Therefore, it is a question that worth consideration about how colleges and universities of finance and economics that focus on application area develop management science well that emphases on Mathematical theory. Based on the in-depth analysis of running situations of Management Science in domestic colleges and universities of finance and economics and combined with our own experience in education, we put forward corresponding reform thinking and practice for current running issues of management science major in colleges and universities of finance and economics.
\end{abstract}

Keywords-Management Science; colleges and universities of finance and economics; construction of a major; orientation

\section{INTRODUCTION}

With the acceleration of the global economic integration, the competition is becoming increasingly fierce. How to transform from previous "empirical" management mode to a "scientific" management mode, and how to establish a scientific and rational management mechanism and use scientific management methods to improve management level have generally become a focus of society attention. Application situation in the economic field in the future as well as the reality demand provides a good opportunity for rapid development of management science disciplines that is combined with finance and economics: the traditional logistics optimization methods and quantitative decision analysis model have been widely used in the field of production operations management, enterprise supply chain management and so on. In addition, with the advent of Big Data thinking, as well as government and enterprises attaching great importance to big data, management science methods, such as data mining and knowledge discovery, are increasingly mature [1,2]. And W.W.

* Corresponding author.

This work was supported by the Professional Promotion Plan of Central University of Finance and Economics.
Wang thought about Big Data is the important resources of the business develop [3].

But what behind the opportunity also makes the construction of Management Science in colleges and universities of finance and economics face enormous challenges, L. Lu has an idea that the concept of scientific management has been criticized in the domestic management of academic since its generated [4]. Thus many scholars had studied about how to construct Management Science Major with Financial Characteristics, for example, J.Y. Miao et al. studied how to improve the professional capacity of Management Science students and their overall quality, and optimize the setup of the curriculum system [5].

Taking development experience of Management Science major in colleges and universities of finance and economics as the principal thing, combined with the development situation in the various universities across the country, we analyze the problems that colleges and universities of finance and economics face during constructing management science major, and detail advantages and disadvantages of that. Finally, we profound countermeasures and suggestions on developing management science major, fitting the actual situation of colleges and universities of finance and economics.

\section{CurRent Situation of the DeVelopment of the SCIENCE IN THE COLLEGES AND UNIVERSITY OF FINANCE AND ECONOMICS}

As described above, management science discipline has broad application prospects on future society development. However, the development of Management Science major in domestic colleges and universities is not optimistic. Colleges and universities that offer management science major are more than 100, of which more than 20 colleges and universities is specialized in finance and economics, facing a serious problem: management science starts late in China with less social 
identity. How to develop management science, a partial science and engineering major, especially in colleges and universities of finance and economics, is a great challenge. How to build management science major with a financial feature by combining the financial background advantages is a problem that is worth thinking.

We analyze and find out some issues that colleges and universities of finance and economics confront while setting up this major, with the combination of current development situation of the management science major in other colleges and universities of finance and economics that also offer this major, as follows:

\section{A. Most Major Orientation in Colleges and Universities Is Clear While the Specific Embodiments Are Missing}

Management Science is an emerging major in our country. According to the definition that is given by the Ministry of Education for this major, management science is a methodology based major, in order to cultivate students to master the quantitative analysis methods and skills to solve practical problems. Following such idea, most of colleges and universities of finance and economics have a clear professional orientation on management sciences major, but most of them don't detail the specific embodiments professional institutions.

\section{B. Social and Students' identity to Management Science Major Still Need to Be Strengthened}

The problem that is continuous with the above one is that low identity of management science major among students. For management science, an undergraduate major, has been involved in the Ministry of education professional directory since 1998, the community is still unfamiliar to this term, and many industries in the community are lack clear positions that professionally suit management science major.

\section{The Curriculum System and Its Content Setting Are Still Insufficient}

The traditional teaching mode of management science is emphasized on the theory teaching, which leads to the lack of the corresponding to the financial background in the contents of the course, and the relative lack of the experiment contents and so on. This allows students to master the theory itself, but they feel confused about whether it is able to apply into the field of finance and economics and how to carry out the practical application, which weaken the students' interest in learning and also makes the student's hands-on ability become the soft underbelly.

\section{The Capability of Faculty Is Partial Weak}

The property of management science major in colleges and universities of finance and economics is partial science and engineering, so how to find teachers with the science and technology as well as the finance and economics background is a critical issue. It is a common problem that the capability of faculty in colleges and universities of finance and economics is weak, therefore the issues concerning about the selection, appointment and cultivation of teachers need to be solved.

\section{E. The Teaching Contents and Methods Need to Be Innovated}

At present, the teaching methods of the course of this subject are mainly confined to the class teaching, computer experiments, etc. Only a few students participate in the challenge cup competition and undergraduate research innovation projects under the guidance of the teachers. It is still difficult for students to apply what they have learned into their social practice.

\section{F. The Combination of Scientific Theory and Practical Application Is not Strong Enough.}

Management Science major possesses a science and engineering background, emphasizing the theoretical research, while colleges and universities of finance and economics stress the practical application. Hence construction of Management Science major in the colleges and universities of finance and economics leads to a question that worth consideration about the combination of theory and financial applications.

\section{ORIENTATION AND EDUCATIONAL IDEAS OF MANAGEMENT SCIENCES IN COLLEGES AND UNIVERSITIES OF FINANCE AND ECONOMICS}

Considering the problems discussed above and according to the orientation of management science major which is given by the Ministry of Education [7], on the basis of taking full account of the external environment, development trends and other issues, combined with their own financial background, we conclude that colleges and universities of finance and economics should orient management science major as follows, (shown in Fig. 1):

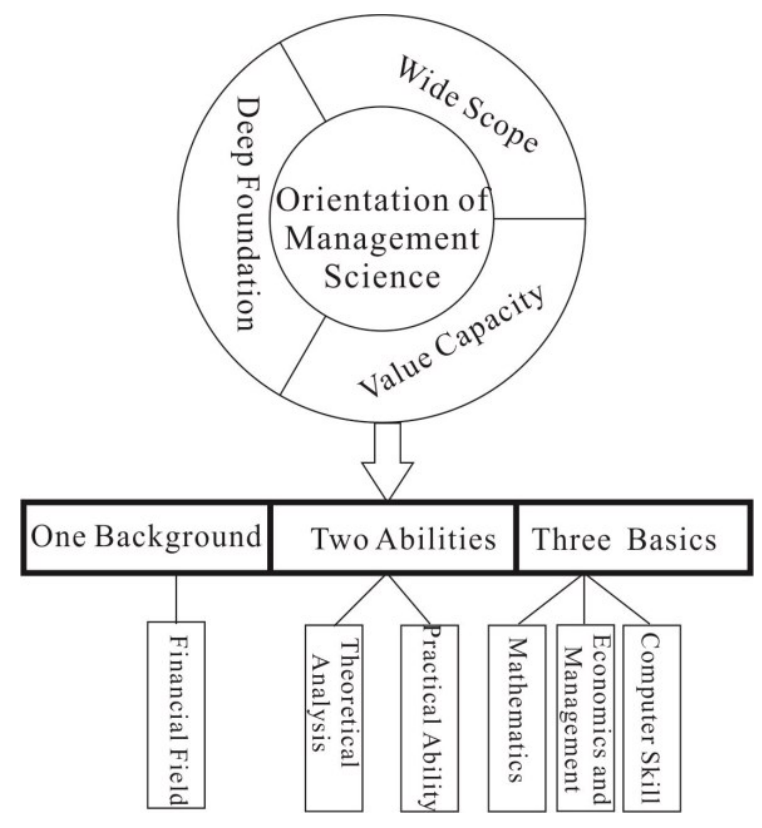

Fig.1. The orientation and educational ideas of management science major

To adapt quantitative management trends, according to the developing ideas "deep foundation, wide scope, value capacity", relying on its own advantages of finance and economics discipline and the basis of traditional management sciences emphasizing quantitative analysis, we should 
strengthen the study of the finance theory to enhance students' practical ability. It enables students to flexibly utilize qualitative and quantitative analysis methods to analyze and solve practical problems in management (especially in the financial field). And students should be encouraged to continue their studies after graduation, not limited to a single major.

\section{A. The Developing Ideas of Management Science Major}

1) "Deep Foundation"

A solid foundation in mathematics, economics and management and computer, should be laid for students.

\section{2) "Wide Scope"}

The students should master multi-disciplinary basic knowledge in the financial field and have more choices when they continue their education or obtain employment in the future.

\section{3) "Value Capacity"}

We should pay attention to develop students' skills on qualitative and quantitative analysis and decision-making, hands-on problem-solving as well as the ability to adapt when they continue their education or enter the industry.

\section{B. The construction Ideas of Management Science Major}

Under the guidance of major orientation, the construction of Management Science major in colleges and universities of finance and economics should comply with the following ideas

\section{1) One Background: Close Combination of Practical} Problems in the Financial Field.

Management Science closely expands around the practical problems of social production and management. The background of the issues in this major falls on the financial field. Thus in the process of training students, case studies in class, guiding extracurricular research, practice teaching, guiding thesis and other links need to be closely around the financial field to implement on the basis of teaching general principles of management science, so that students definitely ensure that application prospect about methods which they learn apply into finance domain.

\section{2) Two Abilities: Theoretical Analysis Capability and} Practical Ability.

If students do not fully digest theory, their future actual operation will like water without source, being bound to the deviation; if students are lack of practical ability, they only can discuss problems in papers instead of solving practical ones. Management Science graduates should reach a level that they both understand the theory and are able to operate, which are indispensable. Understanding the theory does not touch the surface, but requires to deeply know it and know why, and also understand that what problem it can solve in practice as well as how to solve it; being able to operate is not blind, you strictly need to be guided by the theory. In this way, no matter students continue their education or obtain employment in the future, they could show certain competitiveness. In the process of students training, despite the different emphases in different courses and guidance activities, both capabilities should be cultivated in harmony.
3) Three Basics: Mathematics Foundation, the Foundation of Economics and Management, Basic of Computer Skil.l

Based on two points above, the students with a solid mathematical foundation is able to thoroughly understand the theories and methods of quantitative analysis, ones with rich knowledge of economics and management is able to thoroughly comprehend ECONOMIC ISSUES, and ones with proficiency on computer tools is able to actually solve the problem. The above three kinds of bases are decisive factors that whether the students in this major have strong potential development in the future.

\section{REFORM AND PRACTICE OF THE CONSTRUCTION MANAGEMENT SCIENCE MAJOR IN FINANCE AND ECONOMICS COLLEGES AND UNIVERSITIES}

For the issues raised above which colleges and universities of finance and economics face in the process of construction of management science major, combined with major orientation and educational ideas of management science disciplines in them, they should do the following things in the reform and practice of the management science major in the future:

\section{A. Improve Students' Acceptance}

Due to the recognition of students and the limited social environment, it is difficult to resolve the problem of low rate of choosing management science as major in the universities after the College Entrance Examination in a short time. After students' entrance to schools, we need to continue to increase propaganda of this major. When lectures that are given by our professional experts have carried out in-depth at the same time, we invite the alumni of this major back to spread their "personal experience" to enhance students' confidence in the future development. Meanwhile, the Central University of Finance and Economics, for example, with the specialized courses gradually opening, students' interests in professional knowledge increase, and many students actively seek previous guidance of teachers to participate in mathematical modeling contest, research and innovation projects. And many of them select management Science as their majors for master's degree. This suggests that we can increase the introduction about simple expertise and application cases in the financial field to students in freshman stage to ensure that students will generate a strong interest in learning professional knowledge as soon as possible.

\section{B. Strengthen Improvements of Curriculum System and Curriculum Content}

Combined with our own major orientation and financial background, taking in the experience of other colleges and universities, considering the society demand and students feedback, we need to improve the curriculum system and curriculum contents.

Although most of the course system of management science in financial institutions has been relatively completed, the curriculum system and curriculum content still need to be modified, based on their own orientation and social talents needs, combined with the internal communication and survey 
feedback results on students, and the views that are seeking from the relevant teachers:

The professional courses shall start from finance cases augment and the proportion of experimental teaching improvement. Given that the current part of the courses is generally rare application background in the financial field, and thus teachers are required to review extensive literature daily and design experiments teaching. The assignments at the end of courses gradually become one of the assessments of each course. We should also strive to increase the experimental and bilingual classes

\section{Strengthen the Capacities of Faculty}

To solve the issues that the capability of faculty is partial weak which colleges and universities of finance and economics confront High-level talents should be attracted and grow into leaders of this discipline. They share an increasingly heavy teaching workload, being the strong support of part of the weak curriculum. Meanwhile, they also improve the major teacher's knowledge structure more reasonably, promoting the crossing and integration of research direction among teachers. This is the most rapid method to enhance the professional research and teaching level. In addition, in order to development sustainably, we should also focus on teacher training, providing a good environment for the growth of outstanding teachers. How to tap the potential of current teachers and to enhance their teaching level is an even more critical issue.

\section{Actively Implement Education Reform and Accelerate the Construction of Teaching Materials}

According to the outstanding issues in teaching seminars and teaching practice, a small teaching reform team needs to be formed. It declares reform issues, and researches ideas and methods of teaching reform. At the same time, we should choose textbooks and construct case base, which begin with courses that have been taught many times and have rich accumulated materials, and actively strive for excellent course declaration. Textbooks should be written closely linked to training objectives for finance applied talents, which focus on financial background strengthening and the ability of students highlighting. These efforts may start with teachers who have less stress on title as well as assuming the same course, then gradually popularize.

\section{E. Enrich Teaching Methods}

We can choose more diverse ways in class teaching. For instance, when teachers teach some knowledge, students track and grasp the academic front, then report to the class. In this process, it not only enable students generate a deeper understanding of knowledge points, but also exercise their literature search capabilities and skills. On the other hand, inviting industry experts to teach some chapters is a way that some teachers have tried. And we highly recommend it.

In the aspect of theory extracurricular guidance, students form academic groups according to personal interests which are guided by the teachers respectively. It allow student to contact the academic front, and actively participate in various competitions as well as research and innovation projects by participating in academic groups.

In the aspect of practice teaching, we should keep in close contact with teaching practice base and arrange student for internships. This does enable students to apply what they have learned in to reality and this gives full play to the role of teaching practice base. On the other hand, absorbing students into lateral group of teachers, participating in the whole study and undertaking part of the research work, which is now relatively easy method to implement.

\section{F. Strengthen Domestic and International Cooperation}

On the basis of the construction and teaching experience exchange of major in other colleges and universities that has been implemented, we should expand the scope of the communication, by carrying out research discussions and exchange visits and sending exchange students to each other.

We learned that from our research work, the City University of Hong Kong sets up management science major. Its curriculum system is similar to ours. Under the absence of foreign university management science background, we should choose that as a communication target. It is of great significance for the teachers and students of our major to broaden their horizons.

Universities and research institutes gather in Beijing, so there are a wealth of teaching and research resources. It is flexible and convenient for the application in talents training. For example, summer courses of Chinese Academy of Sciences last a short time and have little conflict with our normal teaching, their teachers are high-level, and academic atmosphere there is strong. We could recommend students who have spare capacity to attend lectures. They will benefit from such experience.

Therefore, colleges and universities of finance and economics should strengthen investigation, learn lessons and strengthen cooperation with relevant colleges and universities.

\section{CONCLUSION}

With the development of economic globalization, application of management science in the socio-economic fields is becoming more important and wide-ranging. However, as the management sciences in China starts late and because of the main emphasis on theoretical research, these two factors lead to difficulties during the development of the major in Financial Institutions. Combined with these features, we propose some response strategy: clear orientation, enhance awareness, improve course system, strengthen the construction of teachers' capabilities, enrich teaching methods, and strengthen domestic and international cooperation. We believe it will be a great help scientific in the construction of management science major in colleges and universities of finance and economics. Nevertheless, the pattern of the development of management science major in colleges and universities of finance and economics is still the need to constantly improve, explore, test and improve in practice. 


\section{REFERENCES}

[1] X.B. Huang "The Development Trends of Data Mining and Knowledge Discovery." New Technology of Library \& Information Service, vol. 102 (2003).

[2] M. Mccurt "Why Big Data is Important" [J]. Security Solutions for Enterprise Security Leaders., 2012.

[3] W.W. Wang Big Data Is The Important Resources Of The Business Develop[C] Jiangsu Commercial Forum2015.
[4] L.Lu. "Argument,Dilemma and Solutions of Scientific Management:In the View of Qian's "Technological Science"[J]. Science of Science \& Management of S \& T, 2011.

[5] J.Y.Miao, T. Li, J.LI, "Research on the Training Model of Applied Professionals in Management-Science Major of Financial Universities"[J]. Theory \& Practice of Education, 2015.

[6] Ministry of Education of People's Republic of China, The Undergraduate Professional Directory of the Regular Institutions of Higher Learning. Higher Educational Press, BeiJing 2012. 